\title{
Challenges pre-service teachers face when implementing a 5E inquiry model of instruction
}

\author{
Ramya Enugu ${ }^{1} \&$ Hayat Hokayem ${ }^{1}$ \\ ${ }^{1}$ Texas Christian University, Fort Worth, Texas, USA. \\ For correspondence: h.hokayem@tcu.edu
}

\begin{abstract}
This study examined the challenges that pre-service teachers faced when implementing inquiry and their perspective on how to overcome them. The data sample was 55 pre-service teachers (PSTs) enrolled into two sections of a science methods course in a private university in North Texas. The data sources consisted of inquiry-based lesson plans, PST interviews, peer teaching observational notes, and field notes to investigate those challenges. The data were coded through designed rubrics for lesson plans and peer teaching sessions and were analyzed using the constant comparative method. The results of this study showed that PSTs faced several challenges regarding the science content and the teaching method. The PST face main challenges with the explain and the elaborate phases of the 5E. They also faced challenges difficulties with managing the time to teach the $5 \mathrm{E}$ model, and mapping the lessons to the different parts of the 5E model. The results also showed several solutions such as having solid science content through engaging in different experiences, and having more practice with the $5 \mathrm{E}$ lesson planning. We discuss the implications of this study for teacher education programs.
\end{abstract}

Keywords: 5E teaching model, inquiry, pre-service teacher's (PSTs), teacher education.

This paper is based on the first author's master's thesis research.

\section{Introduction}

Previous research indicates that pre-service teachers(PSTs) develop an ability to teach inquiry if they are prepared and supported in their teacher education programs (Crawford, 1999). Fazio, Melville, and Bartley (2010) indicatedthat PSTs learn different ways of implementing inquiry to teaching science while observing their cooperative teachers during the practicum. McDonnough and Matkins (2010) indicated that if given an opportunity to participate in field experience/practicum along with a science methods course in teacher education programs, PSTs will show greater understanding of research-based teaching practices. Those aforementioned examples indicate the necessity of supporting PSTs to teach inquiry. However, despite the success of some preparation programs in promoting inquiry based teaching, this method still poses many challenges. For example, Yoon, Joung, and Kim (2011) posited that despite taking several science content courses during teacher education programs, many PSTs still lack the necessary science content knowledge, which is one of the challenges they face while using inquiry as a teaching method. Therefore, before preparing PSTs to teach inquiry, there is yet the necessity to thoroughly understand the challenges they face, and this is why we pose the following research questions:

1. What are the challenges faced by PSTs while implementing the 5E inquiry model in their science teaching?

2. What solutions do PSTs propose that can alleviate these challenges? 


\section{Conceptual Framework}

The theory of constructivism stipulates that the learners' minds are not empty vessels, and that when they approach learning, they already have their own ideas and experiences that guide the learning process, therefore, information is stored in memory as elements called "schemes" or "schemas" (Driver et al., 1985). Meador (1988) discussed Jean Piaget's intelligence model and its two main aspects: quality of thought and mental functioning. Mental functioning explains the process of learning in four steps called Assimilation, Disequilibration, Accommodation, and Organization. One way to achieve learning by constructing knowledge is through active engagement using the learning cycle, and the way to teach using the learning cycle is the specific model called the 5E inquiry model.

\section{Learning Cycle and Constructivism}

Karplus, Their, Lawson, Knoll, and Montgomery (1967) indicated that the learning cycle was first used as the model for planning lessons in the Science Curriculum Improvement Study (SCIS). The three phases of the learning cycle are: Exploration, Concept Introduction, and Concept Application. In the Exploration phase, students explore the scientific phenomenon, gather information, and develop their own theories. In the Concept Introduction phase, teachers introduce concepts to students, and the students share their observations and ideas from the previous exploration phase. In the final phase, Concept Application phase, students apply their own developed theories from the previous phases to new scenarios (Bybee et al. 2006).

Meador (1988) indicated that the learning cycle is based on mental functioning, which is one of the main aspects of Piaget's intelligence model. He mapped the phases of the learning cycle to the four steps of mental functioning. The Assimilation step of mental functioning relates to the Exploration phase of learning cycle because students explore the scientific content and grasp ideas from their experiences. In the learning cycle, a person becomes "disequilibrated" sometimes in the exploration phase when he/she is subjected to new circumstances. There is a chance of being re-equilibrated, by assimilating new ideas into already existing schemas. The Accommodation step is related to the Concept Introduction phase of the learning cycle. This is the phase when an individual accommodates a new concept by creating a new mental schema. In both of these phases (exploration and concept introduction), students are expected to share their observations from previous phases and accommodate new concepts by changing or redefining existing schemas. Finally, the Organization step and the Concept Application phase are related to the assimilation phase because students relate and apply the scientific theories to new scenarios.

\section{E Inquiry Model and Constructivism}

One way to implement the learning cycle is through the 5E teaching inquiry model. Bybee (2015) argues that the 5E model is still an effective method for teachers to design science lessons aimed at meaningful understanding and active construction of knowledge. In addition to the exploration, concept introduction, and concept application phases of learning cycle, Bybee et al.(2006) added two additional phases which are the engage and evaluate. Therefore, the 5E model has five phases: Engage, Explore, Explain, Elaborate, and Evaluate. The three phases of the learning cycle (Exploration phase, Concept Introduction phase, and Concept Application phase) align with explore, explain, and elaborate phases of the 5E model respectively. The initial engage phase is a new phase during which teachers assess students for their prior knowledge and generate students' interest concerning the topic at hand. In the second explore phase, teachers ask provoking questions which encourage students to get involved in various hands-on/minds-on activities to find answers to their questions. This phase is akin to the exploration phase of the learning cycle when students are encouraged to explore. In the third explain phase, teachers encourage students to explain the concept and relate it to the big ideas they learnt from the exploration phase. Students are asked to discuss the results of their investigations and together with the teacher provide the necessary explanation regarding the topic. This phase is 
similar to the concept introduction phase of the learning cycle when students are provided with opportunities to explain their ideas. The fourth elaborate phase is when teachers provide an opportunity for the students to make connections and apply their newly acquired knowledge to solve problems in real-life situations. This phase aligns with the concept application phase of the learning cycle, as they both encourage students to make connections and apply what they have learnt. The final evaluate phase is a new phase during which teachers assess students to check their understanding of the concepts and evaluate their progress. Table 1 shows the relationship of the learning cycle to the 5E model which are both linked to constructivism.

Table 1. Relation between mental functioning of Piaget's intelligence model, learning cycle and 5E model

\begin{tabular}{|c|c|c|}
\hline $\begin{array}{l}\text { Steps of Mental } \\
\text { Functioning }\end{array}$ & Phases of Learning cycle & Phases of 5E model \\
\hline $\begin{array}{l}\text { Assimilation: similar to } \\
\text { Students imbibe ideas } \\
\text { from experience and } \\
\text { pass them through } \\
\text { mental structures } \\
\text { (Meador, 1988) } \\
\text { similar }\end{array}$ & $\begin{array}{l}\text { Exploration phase: similar to } \\
\text { Students explore scientific } \\
\text { phenomenon, gather } \\
\text { information and develop their } \\
\text { own theories (Lawson et al., } \\
\text { 1989; Walbert, n.d.). } \\
\text { o }\end{array}$ & $\begin{array}{l}\text { Engage (new phase): Teachers assess } \\
\text { students for their prior knowledge and } \\
\text { generate students' interest concerning } \\
\text { the topic they teach. } \\
\text { Explore: Teachers ask provoking } \\
\text { questions which encourages students to } \\
\text { explore. In the process of finding } \\
\text { answers to their questions, students get } \\
\text { involved in various hands-on/ minds- } \\
\text { on activities. }\end{array}$ \\
\hline $\begin{array}{l}\text { Disequilibrium: } \\
\text { Students are not clear } \\
\text { about meaning of } \\
\text { some data, it does not } \\
\text { fit mental structures } \\
\text { (Meador, 1988) similar } \\
\text { Accommodation: } \\
\text { Students are expected } \\
\text { to accommodate new } \\
\text { concepts, change and } \\
\text { reinvent mental } \\
\text { structures (Meador, } \\
\text { 1988) }\end{array}$ & $\begin{array}{l}\text { Disequilibration may or may } \\
\text { not occur in the exploration } \\
\text { phase (Meador, 1988) }\end{array}$ & $\begin{array}{l}\text { similar to } \\
\text { to explain: Teachers encourage students } \\
\text { to explain the big ideas they learnt from } \\
\text { the exploration phase. Students are } \\
\text { asked to discuss the results of their } \\
\text { investigations and teachers provide the } \\
\text { necessary explanation regarding the } \\
\text { topic. }\end{array}$ \\
\hline $\begin{array}{l}\text { Organization: }: \text { similar to } \\
\text { Students relate and } \\
\text { organize mental } \\
\text { structures (Meador, } \\
\text { 1988) }\end{array}$ & $\begin{array}{l}\text { Concept Application phase: } \\
\text { Students apply their own } \\
\text { theories developed in previous } \\
\text { phases to new scenarios } \\
\text { (Walbert, n.d.). }\end{array}$ & $\begin{array}{l}\text { to } \\
\text { Elaborate: Teachers provide an } \\
\text { opportunity for the students to make } \\
\text { connections and apply their newly } \\
\text { acquired knowledge to solve problems } \\
\text { in real-life situations. } \\
\text { Evaluate (new phase): Teachers assess } \\
\text { students to check their understanding } \\
\text { of the concepts and evaluate their } \\
\text { progress }\end{array}$ \\
\hline
\end{tabular}




\section{Literature Review}

Pre-service teachers (PSTs) face two kinds of challenges in the process of coping with K-12 classrooms 1) general challenges that are common to all teachers and, 2) the specific challenges that pertain to science teaching using inquiry.

\section{General Challenges}

Ferber and Nillas (2010) conducted a study to observe the challenges and successes faced by PSTs during their student teaching experiences. Some of the challenges were interactions between teacher candidates and their cooperative teachers, time and classroom management issues, and the lack of feedback from cooperative teachers. Sadler (2006) reported challenges such as the difficulty of managing students with special needs, and the huge time consumption required tocomplete paperwork. Student teachers in this study held teacher education programs accountable for their inability to deal with the challenges aforementioned. Similarly, Fantilli and McDougall (2009) investigated novice teachers' experiences as they were promoted from pre-service to in-service teachers. In addition to the common classroom management challenges, lack of experience communicating with parents, and inadequate classroom resources were some of the additional challenges that novice teachers had to deal with. Davis, Petish, and Smithey (2006) conducted a thorough literature review related to the challenges of new science teachers. The review showed five issues related to the understanding of the content and disciplines of science, the learners, the learning environments, the instruction, and professionalism. They concluded that new science teachers face difficulty in meeting all the high expectations set by national standards. The challenges they faced could not always be overcome by reforming teacher education programs, and there is need for some challenges to be addressed at the institutional or policy level.

Those general challenges stand in the way of teaching excellence. One can think that those challenges lead to the continuation of traditional teaching where teachers disseminate information rather than work on inquiry practices. However, even when teachers overcome the general challenge, teaching inquiry has its own specific challenges.

\section{Challenges faced by PSTs using Inquiry}

Despite the importance of inquiry, many challenges stand in the way of its successful implementation. Recent research has shown that in the process of learning to teach science efficiently, PSTs find inquiry and its methods to be perplexing (e.g., Crawford 1999; Windschitl \& Thompson, 2006). Novices and PSTs face challenges trying to alter or improvise the instruction in response to a learner-centered inquiry instruction and also struggle with poor content knowledge. One study with elementary PST's found that the difficulties they face are associated with pre-diagnostic assessment, choosing the appropriate mode of instruction, appropriate implementation of instruction, and improvisation when needed (Zembal-Saul, Starr, \& Krajcik, 1997). Most PSTs, for example, find difficulty in linking science content knowledge with pedagogy and fail to make use of their own knowledge to improve students' learning (Ball, 2000).

Not only do American teachers face challenges with teaching inquiry, but also many international teachers as described by Abd-El-Khalick et al. (2002). He mentioned some of the challenges across different countries, which are as follows: 1) Absence of a clear framework for inquiry and the nature of science in the science curriculum which caused confusion for teachers in Venezuela and Lebanon, 2) More emphasis on the hands-on rather than minds-on component of inquiry in Lebanon, 3) Inquiry based laboratories which require huge financial support, proper training, and massive commitment efforts across the whole educational system in Israel, 4) Lack of proper implementation of inquiry in Australia, and 5) Inclusion of large amounts of content material in Taiwan. Black (2004) conducted a study in Canada to learn about the challenges of PSTs during their student teaching practicum. She 
reported the major challenge of extensive preparation before teaching which required teachers as a hindrance to using inquiry.In another study, Kang, Bianchini, and Kelly (2013) found that PSTs were willing to implement science as inquiry but found difficulty in bridging their subject knowledge with pedagogy. Schulz and Mandzuk (2005) examined how teacher candidates in their new pre-service teacher program "defined, understood, and experienced" inquiry (p. 327). PSTs found the ability to multi-task in the classroom while teaching open-ended inquiry challenging. PSTs also noticed a discrepancy between the theories they learnt in teacher education program to what in-service teachers practiced in the K-12 classrooms. Whereas the teaching method courses emphasized extensive planning, the in-service teachers were spontaneously teaching without much planning.

There was one study that recently examined challenges of using the 5E model in the classroom. Sickel and Friedrichsen (2015) conducted a study to understand how a beginning science teacher designed and taught a complete $5 \mathrm{E}$ unit on natural selection to tenth graders. In the first year of her teaching, she taught an inquiry-based unit emphasizing all phases of the 5E model. She identified students having difficulty in discovering the concepts in the "explore" and the "elaborate" phases of instruction. Sickel and Friedrichsen (2015) examined how her teaching changed over the second and the third years when she moved to another school district. In the second and third years, she emphasized the explore phase, deemphasized the explain phase, and omitted the elaborate phase. She posited that the challenges, like time management and working with colleagues who did not share similar inquirybased views, as reasons for not implementing all the phases of the 5E model. In addition to these challenges, students also faced problems in explaining and elaborating the concepts, which made her emphasize the explore phase rather than blindly explaining the concepts. This case study stands as an example for beginning science teachers to use the "constructivist sequence of instruction" despite several challenges.

In contrast to other studies, Hanuscin and Lee (2008) conducted a study which showed that PSTs successfully "practiced" what was "preached" in the teacher education programs. Researchers (teacher educators) were aware of the challenges PSTs face while implementing inquiry instruction when they applied the 5E learning cycle model. The activities they developed for their own teaching using the learning cycle helped their students (PSTs) to develop a deeper understanding of ways to choose activities for their own instruction. For example, PSTs with this approach developed the skill of selecting and sequencing activities in a meaningful way for teaching inquiry. This approach helped PSTs learn effective ways to implement inquiry as they observed their teacher educators model inquiry-based instruction, minimizing the challenges associated with teaching inquiry.

The aforementioned literature demonstrates plethora of challenges and scarcity of offered solutions. The challenges were mainly general challenges and do not specifically relate to the $5 \mathrm{E}$ model. Therefore our study contributes to the literature by teasing apart the specific challenges that preservice elementary teachers face when teaching using the 5E inquiry model, and the solutions they propose to alleviate those challenges.

\section{Methodology}

\section{Sample and Setting}

The participants in this study were 55 PSTs who were specializing in elementary education in a private university in North Texas. They were expected to complete a science methods course for elementary education which focused on ways to implement inquiry in their science teaching. The course work was divided into three different parts: inquiry-based lesson planning, peer teaching, and teaching inquiry-based science lessons in the K-12 classroom. All those lessons were supposed to be taught using the 5E inquiry model. The classes consisted of modeling the 5E inquiry model and extensive practice and reading to support them in developing inquiry practices. The PSTs wrote 
lesson plans and taught to their peers in the university classrooms (peer teaching sessions) and to elementary students in the field (field teaching).

\section{Data Sources}

Surveys and semi-structured interviews. There were two surveys. First, PSTs were given an open-ended written pre-course survey during the first class of the course. Then towards the end of the course, post-course surveys were given which were similar to the pre-course survey questions. Appendices $\mathrm{A}$, and B in the supplementary materials show examples of the completed pre and post-course surveys. Semi-structured interviews were conducted with a sub group of 15 PSTs. We asked them about the challenges, advantages, and disadvantages of the $5 \mathrm{E}$ inquiry model. Appendix $\mathrm{C}$ shows example of a transcribed interview (questions and answers of the participant).

Inquiry-based lesson plans and peer teaching observations. As part of the science methods course, PSTs were asked to write inquiry-based lesson plans. Each group had to write two lesson plans: one that they taught in the field with elementary students, and one that they taught in the class and the instructor gave them feedback. Most PSTs worked in pairs, and we had total of 26 field lesson plan groups, 26 peer teaching lesson plan groups, and 26 peer teaching session groups. We analyzed the lesson plans based on the lesson plan rubric we designed, which is in Appendix D. The score on the rubric categorized PSTs performance of writing lesson plans into three levels: low, medium and high. A lesson plan score of 1-25 points was categorized as low level performance, while a score of 25-40 points was categorized asmedium and a score of 40-50 points was categorized ashigh level performance. In addition to the above data sources, we also collected observational notes in class. We evaluated the peer teaching sessions based on the peer teaching evaluation criteria, examples of which are in Appendix E. Based on the evaluation of the peer teaching sessions, PSTs performance in the peer teaching sessions was also categorized into three levels of performance namely low, medium and high. The qualitative descriptions of high, medium and, low levels of performance are described in the Appendix F.

Interview with an in-service teacher. We also interviewed an in-service teacher who was one of the mentor teachers to some of the groups about the challenges she faced and compared that with preservice teachers' views about the challenges.

\section{Data Analysis}

We coded the data of this study by using axial coding. Corbin and Strauss (2014) defined axial coding as a set of procedures which are used for making connections between various data sources. Axial coding is a process of creating categories or themes by grouping codes (tags given to words and phrases) from data. However, as with any qualitative research, the coding is an iterative process. Even though we started with an initial coding scheme, we revised the codes depending on the empirical data and the emerging themes. This procedure aligns with Corbin and Straus's (2014) constant comparative method of examining one piece of data's relationship to another piece. In the constant comparative method, data is broken down into pieces. For example, the constant comparison of pre-course surveys and post-course surveys indicated that the PSTs implementing 5E inquiry model are facing difficulty with the time required to finish implementing the $5 \mathrm{E}$ lesson plan. This challenge is categorized as a theme called "lesson planning using $5 \mathrm{E}$ model is a time consuming process." We show some other examples in Appendix G. This triangulation of multiple data sources served as a method to validate our emerging themes.

Concerning reliability, the two authors coded the two lesson plans and the peer teaching sessions separately. We had an agreement of over $90 \%$, and any disagreement was resolved through discussion. 


\section{Results}

The results of this study showed the two kinds of challenges regarding using the 5E teaching model: content related challenges and method related challenges. Moreover, the PST reported several ways by which they might alleviate those challenges. We report on the challenges and solutions below:

\section{Content related Challenges}

Writing and implementing the explain phase of the 5E model. Various data sources like field lesson plans, peer teaching lesson plans, and peer teaching sessions indicated that the Explain phase of the 5E model is challenging for PSTs. Their reference to the explanation was classified into three categories. The first refers to those having a complete explanation (PSTs had the complete and correct scientific explanation), the second refers to those having a partial scientific explanation (PSTs had some sound scientific ideas, but did not include all ideas of the scientific explanation), and the third refers to those having poor scientific explanations (PSTs had incorrect scientific explanation). Table 2 shows the percentages of PSTs struggling with the Explain phase.

Table 2. Percentage of PSTs struggling with Explain phase

\begin{tabular}{llll}
\hline \multicolumn{1}{c}{ Data Sources } & $\begin{array}{c}\text { Indicated Complete } \\
\text { Scientific Explanations }\end{array}$ & $\begin{array}{c}\text { Indicated Partial } \\
\text { Scientific Explanations }\end{array}$ & $\begin{array}{c}\text { Indicated Poor } \\
\text { Scientific Explanations }\end{array}$ \\
\hline Field lesson plans & $41.82 \%$ & $50.91 \%$ & $7.27 \%$ \\
& $(11$ groups $)$ & $(13$ groups $)$ & $(2$ groups) \\
Peer teaching & $30.91 \%$ & $54.54 \%$ & $14.55 \%$ \\
lesson plans & $(8$ groups) & $(14$ groups $)$ & (4 groups) \\
Peer teaching & $23.64 \%$ & $65.45 \%$ & $10.91 \%$ \\
sessions & $(6$ groups) & $(17$ groups $)$ & (3 groups) \\
\hline
\end{tabular}

Table 2 shows that only $30.91 \%$ (8 groups) had complete scientific explanations in their peer teaching lesson plans, but only $23.64 \%$ (6 groups) had complete scientific explanations during their peer teaching sessions. Similarly, 54.54\% (14 groups) had partial scientific explanation in their peer teaching lesson plans, and 65.45\% (17 groups) had partial scientific explanation in their peer teaching sessions. This discrepancy between peer teaching lesson plans and peer teaching sessions (Table 2) indicates that the PSTs who wrote the peer teaching lesson plans could not successfully implement them as expected to present the complete scientific explanations. For example, P-10 and P-23 in their peer teaching lesson plan on plate tectonics, indicated partial explanations ("We will discuss the results of the experiments to show the reason behind movement of the earth's surface, give definitions of different types of plate movements.") However, in the peer teaching session, they failed even to do that. Rather than discussing the results of the experiments as mentioned in their lesson plan, they skipped the discussion part and read out definitions directly from the slides. They failed to motivate students to relate the graham cracker activity to plate tectonics movements. The overall explain phase was very vague, as they did not explain deeply how the tectonic plates interact, which made it fall under the poor scientific explanation category. To better illustrate those three categories, I will focus on the lesson plans and present the details in specific lesson plans that explain each case. Table 3 presents a case of a PST group having a complete scientific explanation.

Table 3. Data showing Complete Scientific Explanation

\begin{tabular}{|c|c|}
\hline $\begin{array}{l}\text { Name of the PST and Objective of the } \\
\text { Lesson }\end{array}$ & Complete Scientific Explanation \\
\hline$P-40$ and $P-43$ & $\begin{array}{l}\text { "We will begin introducing the topic of fossils by } \\
\text { first asking students to define the term fossils, } \\
\text { discuss their definitions. } \\
\text { We will define the term fossils and discussing the }\end{array}$ \\
\hline
\end{tabular}




\section{Peer teaching lesson plan}

Objective: Students will be able to identify fossils as evidence of past living organisms and evidence of history. attributes of fossils.

Fossils are what is left from living things in the past

Fossils can be prints of animals or plants

Some fossils are parts of things that were once living (Bones, Teeth)

The next main idea we will address is where geologists can find fossils.

- In rock

- Ice

- Tar

- Amber (hardened tree sap)

The final main idea we will discuss is how fossils are made.

Animals die, their remains stay behind

Over many, many years the remains are buried

- Soil

- Clay

- Mud

The layers turn to rock and the remains leave an imprint in the rock

This imprint is called a

We will then ask students to write down what they learned, making sure to point out our key idea which is that fossils are evidence of past living organisms."

The example in Table 3 shows a complete scientific explanation. The lesson was about fossils. PSTs divided the explain phase into three parts. The PST's asked students to come up with the definition for fossils in the first part. They explained where the fossils were found in the second part, and finally, they addressed the main idea of how fossils were formed in the third pat. At the same time, the PSTs asked students to write down what they learned from the lesson to check whether students understood the big idea. We called this a complete scientific explanation because they had the right balance of questions, discussion and appropriate explanations.

Moreover, Table 4 shows an example illustrating partial scientific explanation.

Table 4. Data showing Partial Scientific Explanations

\begin{tabular}{|c|c|}
\hline $\begin{array}{c}\text { Name of the PST and Objective of the } \\
\text { lesson }\end{array}$ & Partial scientific explanation \\
\hline $\begin{array}{l}\text { P- } 30 \text { and P-53 } \\
\text { Peer Teaching Lesson Plan } \\
\text { Objective: The students will be able to } \\
\text { identify different states of matter and } \\
\text { distinguish between them. }\end{array}$ & $\begin{array}{l}\text { - "After sorting the pictures we all reconvene } \\
\text { as a class. } \\
\text { - On the whiteboard we will have } \\
\text { constructed a chart and as a class fill it in } \\
\text { together. } \\
\text { - Groups will be called on one at a time to } \\
\text { give an example and reason why they } \\
\text { sorted in certain way. } \\
\text { After giving their example if any groups } \\
\text { dispute their thoughts, we will discuss as a } \\
\text { class." }\end{array}$ \\
\hline
\end{tabular}


The example in Table 4 shows partial scientific explanation. The lesson was about states of matter and the ability to distinguish between them. PSTs planned to discuss the activity (sorting pictures according to the state of matter) and the criteria by which students sorted the pictures. Even though PSTs provided students with the opportunity to explain their criteria (shape, texture, etc.) for sorting objects, they neither addressed the reason behind choosing those criteria, nor did they provide students with the appropriate explanation which pertained to molecular representations in solids, liquids, and gases. At the same time they did not have any critical questions which could further help students to think deeply about the differences between the different states of matter. Another illustration is of a case representing poor scientific explanation in Table 5.

Table 5. Data showing Incomplete and Poor Scientific Explanations

\begin{tabular}{|c|c|}
\hline $\begin{array}{l}\text { Name of the PST and Objective of the } \\
\text { Lesson }\end{array}$ & Incomplete and Poor Scientific Explanation \\
\hline P-5 and P-9 & $\begin{array}{l}\text { - Bring the class together and draw a table on } \\
\text { the board with each group's name on it. }\end{array}$ \\
\hline Peer teaching lesson plan & $\begin{array}{l}\text { Record each group's initial prediction of } \\
\text { which liquids were more or less dense. }\end{array}$ \\
\hline $\begin{array}{l}\text { Objective: The students will be able to } \\
\text { engage in the experiment of layering } \\
\text { different liquids and after be able to relate } \\
\text { how liquids layering is related to their } \\
\text { density. They also need to understand what } \\
\text { density is. }\end{array}$ & $\begin{array}{l}\text { Based on their final product, ask students } \\
\text { how they arrived at that by discussing } \\
\text { which liquids the students found to be } \\
\text { successful in layering and how it compared } \\
\text { to their initial prediction. } \\
\text { - Next we will reveal the identity of the } \\
\text { liquids that the students were using. } \\
\text { Ask the students whether they were } \\
\text { surprised after knowing what the real } \\
\text { liquids were (encourage class discussion) }\end{array}$ \\
\hline
\end{tabular}

The example in Table5 shows incomplete and poor scientific explanation. The lesson was about the concept of density and understanding how different liquids have different densities. For the explanation part of the lesson, PSTs chose to discuss which liquids were layered on top and which were layered on the bottom, but failed to relate layering to the density and to define and explain what density means. They had few questions about which liquids were on top and whether this was what they had predicted, but they did not motivate the students to think that density was the reason behind why liquids layered the way they did. Moreover, they failed to provide students with the scientific explanation behind the concept of density as it relates to mass and volume.

Difficulty evaluating students' understanding. Similar to the explain phase of the 5E, PSTs struggled with evaluating students' understanding of the scientific concepts. During the interviews, $13.33 \%$ of the PSTs said that evaluating students understanding at the end of the lesson was challenging. We found that PSTs evaluations or reference to the evaluations were classified into three categories. The first refers to those having a complete evaluation, the second refers to partial evaluations where students hadan evaluation task which targeted part but not all the concepts in their lesson objective, and the third refers to incomplete evaluation when PSTs skipped the evaluation phase.Table 6 shows the percentage of PSTs struggling with the Evaluate phase. 
Table 6.Percentage of PSTs struggling with the Evaluation phase

\begin{tabular}{llll}
\hline \multicolumn{1}{c}{ Data Sources } & \multicolumn{1}{c}{$\begin{array}{c}\text { Indicated Complete } \\
\text { Evaluation }\end{array}$} & $\begin{array}{c}\text { Indicated Partial } \\
\text { Evaluation }\end{array}$ & $\begin{array}{c}\text { Indicated Incomplete } \\
\text { Evaluation }\end{array}$ \\
\hline Field Lesson Plans & $80 \%$ & $12.73 \%$ & $7.27 \%$ \\
& $(21$ groups $)$ & $(3$ groups $)$ & $(2$ groups $)$ \\
Peer Teaching Lesson Plans` & $74.54 \%$ & $14.55 \%$ & $10.91 \%$ \\
& $(19$ groups $)$ & $(4$ groups $)$ & $(3$ groups) \\
Peer Teaching Sessions & $69.09 \%$ & $23.64 \%$ & $7.27 \%$ \\
& $(18$ groups $)$ & (6 groups) & (2 groups) \\
\hline
\end{tabular}

As shown in Table 6, 14.55\% (4 groups) had partial scientific evaluation in their peer teaching lesson but the number increased to $23.64 \%$ (6 groups) during their peer teaching sessions. Similarly, $74.54 \%$ (19 groups) had complete scientific evaluation in their peer teaching lesson plans but only $69.09 \%$ (18 groups) had complete scientific evaluation in their peer teaching sessions. This discrepancy between peer teaching lesson plans and peer teaching sessions indicates that the PSTs who wrote the peer teaching lesson plans could not successfully implement them as planned during the peer teaching sessions.To better understand the challenges PST faced with the evaluation phase of the 5E, we present a case for each category. Table 7 presents a case that shows complete evaluation in the lesson plan.

Table 7. Data showing Complete Evaluation

\begin{tabular}{|c|c|}
\hline $\begin{array}{l}\text { Name of the PST and Objective of the } \\
\text { Lesson }\end{array}$ & Complete Evaluation \\
\hline$P-43$ and $P-40$ & $\begin{array}{l}\text { "Very Good Extend activity to assess what they } \\
\text { learned. They had very good questions to push } \\
\text { students thinking" }\end{array}$ \\
\hline Peer Teaching Session & $\begin{array}{l}\text {-They gave each table one fossil mold and have } \\
\text { students create a story about the fossil followed by } \\
\text { few questions. }\end{array}$ \\
\hline $\begin{array}{l}\text { Objective: Students will be able to identify } \\
\text { fossils as evidence of past living organisms } \\
\text { and evidence of history }\end{array}$ & $\begin{array}{l}\text {-What animal do you think the fossil is from? } \\
\text {-Where do you think it was formed? } \\
\text {-How do you think this could have been made? } \\
\text {-Create a story about how this fossil was formed, } \\
\text { incorporate the above three questions. } \\
\text {-Have groups share their story and information } \\
\text { about their fossil to the entire class. } \\
\text {-Reveal what the fossil actually represents and a } \\
\text { few facts about the fossil" }\end{array}$ \\
\hline
\end{tabular}

In Table 7, the example shows the complete evaluation. The lesson was about fossils. PSTs asked students to create a story by incorporating some questions which motivated students thinking about fossils, and how they were formed. The different groups in the class were able to support their story with logical evidence and information about the fossils (e.g., formed in sedimentary rocks over a long period of time) that they learned in the lesson. One could see that this assessment perfectly aligned with the lesson objective and instructional method.

Table 8 shows example of partial scientific evaluations. 
Table 8.Data showing Partial Evaluation

\begin{tabular}{|c|c|}
\hline $\begin{array}{c}\text { Name of the PST and Objective of the } \\
\text { Lesson }\end{array}$ & Partial Evaluation \\
\hline P-12 and P-26 & "Why does it rain more in some places?" \\
\hline Peer Teaching Lesson Plan & $\begin{array}{l}\text { Students answer: "We're going to watch a video about } \\
\text { the rain shadow effect and why it rains more in certain } \\
\text { places." }\end{array}$ \\
\hline Objective: Students will describe and & https://www.youtube.com/watch?v=YWZ6yEv-gI4 \\
\hline illustrate the movement of the water & "Now when you see it rain, you will know exactly \\
\hline $\begin{array}{l}\text { above and below the Earth through the } \\
\text { water cycle, and explain role of the Sun in } \\
\text { the process. }\end{array}$ & how it's happening!! \\
\hline
\end{tabular}

The example in the Table 8 shows partial evaluation. The lesson was about the movement of water in the water cycle and the role of the Sun in the water cycle. PSTs in the evaluation section chose to ask questions and show a video about the rain shadow effect. The video and questions were not very specific to the objective of the lesson. This is partial evaluation because instead of assessing students for their understanding about the water cycle, and the role of different elements (e.g., sun) in the water cycle, this group of PSTs asked students why it rains more in some places and showed a video about the rain shadow effect. Such questions reinforce the idea of condensation and saturation in the atmosphere to produce rain (one phase of the water cycle), but it does not allow one to assess students' understanding of the different phases of the water cycle and the relationships among them.

Another case shows an incomplete evaluations and is presented in Table 9.

Table 9. Data showing Incomplete Evaluation

\begin{tabular}{|c|c|}
\hline $\begin{array}{c}\text { Name of the PST and Objective of the } \\
\text { Lesson }\end{array}$ & Incomplete Evaluation \\
\hline$P-3$ and P-33 & $\begin{array}{l}\text { "We will pass out a short quiz that we have found. } \\
\text { We expect the students to finish this quiz pretty }\end{array}$ \\
\hline Field Lesson Plan & $\begin{array}{l}\text { quickly and will help read if necessary. We also } \\
\text { expect the students to have little issues with }\end{array}$ \\
\hline $\begin{array}{l}\text { Objective:Students will be able to define and } \\
\text { distinguish the four different season and } \\
\text { weather that occurs in each season. }\end{array}$ & $\begin{array}{l}\text { understanding what the quiz is asking and hope } \\
\text { that the students are able to answer all these } \\
\text { questions correctly. We will give the students } 10 \\
\text { minutes to take this quiz." }\end{array}$ \\
\hline
\end{tabular}

The example in Table 9 shows an incomplete evaluation. The lesson was about different seasons and weather that occur in each season. As part of their assessment, the PSTs wrote in their lesson plan that they would pass out a short quiz to assess student understanding, but nowhere did they include any specific questions for this quiz.

The Elaborate phase of the 5E lesson is difficult. The results showed that $20 \%$ of the PSTs found the elaborate phase to be difficult. For example P-31 said in her interview that, "The elaborate part for me was always a little bit more vague or harder to do." We, therefore, analyzed the field and peer teaching lesson plans closely to report percentage of PSTs facing difficulties in the elaborate phase which are reported in Table 10. 
Table 10. Percentage of PSTs facing Difficulty in the Elaborate Phase

\begin{tabular}{lllll}
\hline Phase of 5E & Interviews & Field Lesson Plans & $\begin{array}{c}\text { Peer Teaching Lesson } \\
\text { Plans }\end{array}$ & $\begin{array}{c}\text { Peer Teaching } \\
\text { Sessions }\end{array}$ \\
\hline Elaborate & $20 \%$ & $30.91 \%$ & $43.63 \%$ & $52.72 \%$ \\
& (3 PSTs) & (8 groups) & (12 groups) & (14 groups) \\
\hline
\end{tabular}

As shown in Table 8, 43.63\% (12 groups) of PSTs struggled with the elaborate phase of the 5E model. A more qualitative analysis of this challenge shows that PSTs may have misunderstood the elaborate phase. For instance, in a lesson where students were supposed to learn the difference between conductors and insulators, P- 1 and P-55 in the elaborate phase wrote that they would "introduce the terms conductor and insulator through a short PowerPoint." This excerpt clearly shows that the PSTs were introducing terms in the elaborate phase rather than relating the scientific explanation to real-life situations, or transferring the knowledge they learned to explain a new scenario.

\section{Method related Challenges}

Apart from content related challenges, PSTs also struggled while planning the 5E lesson. We present those different challenges below.

Stringent time slots for phases of the 5E model. During their interviews, $13.33 \%$ of PSTs opined that following strict timelines for each of the 5E phases is unrealistic and challenging. P-30 said, "Having a specific time for each ' $E$ ' is kind of hard because it is based on individual lessons. Some lessons might take less time but some might go over."

A close look at the lesson plans also showed that the PSTs could not estimate the approximate duration for the lesson. For example, P-28 and P-32 in their peer teaching lesson plan estimated their teaching about "Structure of the Earth" would take 45 minutes, but they completed the lesson in 32 minutes. These results motivated us to analyze the time it took PSTs to finish their lesson. We noted the time taken by each PST group to complete the peer teaching lesson, and compared that with the time they had predicted to finish teaching as noted in their lesson plan. The results are presented in Table 11.

Table 11. Table comparing difference between Predicted and Actual time taken to finish the lesson.

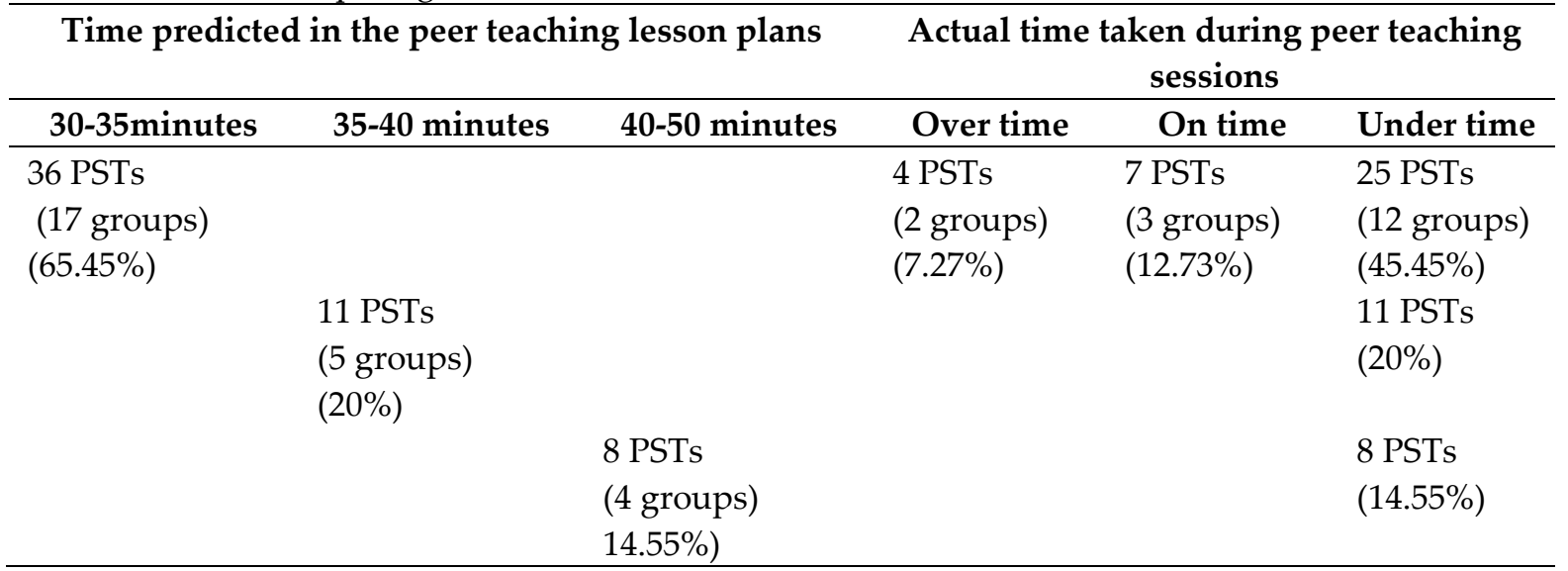

As shown in Table 11, $65.45 \%$ of PSTs (17 groups) estimated the time range of $30-35$ minutes, $20 \%$ (5 groups) estimated $35-40$ minutes, and $14.55 \%$ (4 groups) estimated $40-50$ minutes to implement their lessons in their peer teaching lesson plans. When predicted time ranges were compared to the actual time it took PSTs to implement the peer teaching sessions, only $12.73 \%$ (3 groups) of the PSTs were on time. The rest: $80 \%$ (21 groups) of the PSTs were under time, and $7.27 \%$ (2 groups) of them were over time. 
Knowing that many pre-service teachers did not estimate realistic time periods for their teaching, we further probed their lesson plans to analyze how they allocated time for each of the $5 \mathrm{E}$ phases. Table 12 shows example of unrealistic time slot that was estimated.

Table 12.Excerpts showing unrealistic time slots for different phases of the 5E as shown in their lesson

\begin{tabular}{|c|c|c|c|}
\hline $\begin{array}{l}\text { Name and } \\
\text { Title of the } \\
\text { Lesson }\end{array}$ & Phase & Description & $\begin{array}{c}\text { Time Slot as } \\
\text { predicted by } \\
\text { student }\end{array}$ \\
\hline $\begin{array}{l}\text { P-10, P-23 } \\
\text { Lesson Title: } \\
\text { Plate Tectonics }\end{array}$ & Engage & $\begin{array}{l}\text { "Show a funny video to introduce the lesson. } \\
\text { Relate it to the topics by explaining, "This was a funny } \\
\text { video, but it shows an event that happened over time } \\
\text { millions of years ago and is still happening today. What } \\
\text { do you think happened in the video?" } \\
\text { Link: } \\
\text { https://www.youtube.com/watch?v=TzzGPfVx32M" }\end{array}$ & 3 minutes \\
\hline
\end{tabular}

The example in Table 12 shows that P-10 and P-23, while engaging students to think of "Plate Tectonics", allocated a three-minute time slot for engaging students in the classroom to show and discuss the YouTube video. This time slot seemed unrealistic as the duration of the video was 2 minutes 34 seconds, and there were only 30 seconds left for the whole class discussion.

In addition to time management issues, Table 13shows other method related challenges:

Table 13.Examples of Method related Challenges

\begin{tabular}{ll}
\hline Data Source/Percentage & $\begin{array}{l}\text { Kind of Challenge } \\
\text { Illustration by excerpts from interviews of course surveys. }\end{array}$ \\
\hline $\begin{array}{l}\text { Interviews: 20\% } \\
\text { Pre-course surveys:0.54\% } \\
\text { Post-course surveys:18.18\% }\end{array}$ & $\begin{array}{l}\text { Lesson planning using the 5E is a time consuming process } \\
\text { PSTs opined that the 5E lessons and lesson plans require a lot of } \\
\text { planning and time. For example, P-22 said, "Planning the 5E lesson } \\
\text { is very time consuming." }\end{array}$ \\
\hline & $\begin{array}{l}\text { Making sure every student in the classroom understands the } \\
\text { science content }\end{array}$ \\
& $\begin{array}{l}\text { PSTs expressed concerns about supporting each and every student's } \\
\text { understanding of the science content. For example, P-11 said, "The } \\
\text { challenge would be making the lesson plan for all the students to } \\
\text { Interviews: 20\% } \\
\text { understand it." }\end{array}$ \\
14.55\% & $\begin{array}{l}\text { Mapping the lesson to the different parts of the 5E } \\
\text { PSTs found that dividing any lesson into the 5Es is challenging. P-7 } \\
\text { said, "We had a problem in dividing the lesson into the different } \\
\text { 5Es." }\end{array}$ \\
\hline Interviews: 13.33\% & $\begin{array}{l}\text { Transition between phases of 5E based lesson } \\
\text { PSTs said that deciding when to move from one phase of the 5E to } \\
\text { another while teaching is challenging. For instance, P-42 said in the } \\
\text { interview that "It is hard to decide when to move on may be, if you } \\
\text { are explaining when to stop and when to go, elaborating the topic." }\end{array}$ \\
\hline Interviews: $6.66 \%$ \\
Post-course surveys: $5.45 \%$
\end{tabular}

Despite all of the reported challenges, PSTs proposed possible solutions to the challenges they faced. Table 14related the proposed solutions to the challenges found in this study. 
Table 14.Relating Proposed Solutions to the Challenges of PSTs

\begin{tabular}{|c|c|}
\hline Challenges & Solutions \\
\hline $\begin{array}{l}\text { Lesson planning using the } 5 \mathrm{E} \text { is a time } \\
\text { consuming process. }\end{array}$ & $\begin{array}{l}\text { Using multiple resources to reduce the } \\
\text { time taken to plan 5E lessons. }\end{array}$ \\
\hline $\begin{array}{l}\text { Mapping the lesson plan to different parts of } \\
\text { the 5E. }\end{array}$ & $\begin{array}{l}\text { Practicing } 5 \mathrm{E} \text { lesson plan writing which } \\
\text { helps PSTs to map the lesson plan easily } \\
\text { to the different phases of the } 5 \mathrm{E}\end{array}$ \\
\hline \multirow[t]{3}{*}{$\begin{array}{l}\text { The Elaborate phase of the } 5 \mathrm{E} \text { lesson is hard to } \\
\text { think of. }\end{array}$} & $\begin{array}{l}\text { - Being flexible with } 5 \mathrm{E} \text { division, and } \\
\text { merging phases of } 5 \mathrm{E} \text { aids in planning the } \\
\text { elaborate phase. }\end{array}$ \\
\hline & $\begin{array}{l}\text { Relating the science concepts to real life } \\
\text { experiences to overcome the confusion of } \\
\text { writing the elaborate phase. }\end{array}$ \\
\hline & $\begin{array}{l}\text { - Having a solid science content knowledge } \\
\text { aids in planning the elaborate phase. }\end{array}$ \\
\hline \multirow{3}{*}{$\begin{array}{l}\text { Making sure every student understands the } \\
\text { lesson }\end{array}$} & - Incorporating different teaching strategies \\
\hline & $\begin{array}{l}\text { like direct instruction, indirect } \\
\text { instruction, and independent study helps }\end{array}$ \\
\hline & $\begin{array}{l}\text { PSTs to meet the needs of all students in } \\
\text { the classroom. }\end{array}$ \\
\hline $\begin{array}{l}\text { Writing and implementing explain phase of } \\
\text { the } 5 \mathrm{E}\end{array}$ & $\begin{array}{l}\text { Having a solid science content knowledge } \\
\text { allows PSTs to focus on appropriate } \\
\text { scientific explanations }\end{array}$ \\
\hline
\end{tabular}

As shown in Table 14, the analysis of the lesson plans and peer teaching sessions clearly indicated that the PSTs struggled with the 5E lesson planning in terms of the time taken to prepare the highquality lessons that followed this model. Sadler (2006) agrees with this and states that PST "felt overwhelmed by the amount of time required to develop lesson plans, classroom activities and parental communications via e-mail" (p. 225). As a solution, PSTs posited that seeking help from cooperative or experienced teachers about what works best in the classroom will help in reducing the time taken for 5E lesson planning. Fazio et al. (2010), and Giebelhaus and Bowman (2002) agree that PSTs who team up with trained cooperative teachers, demonstrate better lesson planning and implementation in the classroom. During a conversation with an in-service teacher (who was also a mentor to a few PSTs in this study), we found that she welcomed PSTs' questions and offered help when needed. She recommended that PSTs should be more proactive, ask questions, and seek help whenever they feel unsure about a certain issue.

Another challenge was that the PSTs find the elaborate phase of the 5E model challenging. The PSTs offered three possible solutions for this challenge. The first solution is being flexible while dividing a lesson into the five phases of the lesson plan. One can merge the different phases of the 5E inquiry model. For example one can merge the elaborate and the explain phase which could help alleviate confusion. The second solution is relating the science concepts more to students' real- life experiences. Many agree with this point. In fact, the in-service teacher we interviewed in this study posited that the life experiences of students (visit to museums, zoos, planetariums, magic shows, etc.) make a lot of difference in understanding science concepts. She proposed that the science concepts should be sometimes related to student's experiences outside the classroom and not always to the activities in the classroom. Supporting the in-service teachers' views, Gerber, Cavallo, and Marek (2001) said, "Participation in intellectually and socially instructive activities may stimulate the development of logical thinking skills useful to students' future careers and everyday life" (p. 547). The third solution offered is having a good science content knowledge. Good grip on the subject helps one to divide the lesson easily into 5Es. 
Another very common challenge of PSTs is making sure every student understands the lesson. Every student learns differently, so to meet the needs of every child in the classroom PSTs should develop an ability to incorporate different teaching strategies. This is in line with how McDonnough and Matkins (2010) believe that various instructional methods help in implementing inquiry-based teaching.

Writing and implementing the explain phase of the 5E inquiry model was yet another important challenge that appeared in the results. The possible solution for this challenge is having adequate science content knowledge. Strong science content knowledge helps PSTs design good science lessons and provide complete scientific explanation.

\section{Discussion}

Taking into consideration our results and the literature, we discuss potential reasons for why these challenges exist, and the implication for this study for teacher education programs.

\section{Classroom Management Strategies}

As indicated in the results, PSTs find classroom management challenging. Some PSTs also indicated that the lack of classroom management is the reason for time-related challenges. Good classroom management skills are very important for the teachers to master the art of teaching. According to Grant and Gillette (2006), classroom management and organization provides the framework for teachers to lead students into successful learning outcomes. For any classroom to run smoothly, a good classroom management plan is a must. For instance, Sadler (2006) mentioned how PSTs "adopted relaxed approaches to the classroom management and found that this created immediate problems" (p.225). Results indicated that the PSTs had to try hard to keep students on task, and they also struggled with discipline related issues. If a PST's used good management strategies, students would stay focused on the task and finish work on time, which helps PSTs to implement the lesson as planned.

During our conversation with the in-service teacher, she mentioned that classroom management is the biggest challenge that the PSTs will face. She proposed that PSTs should try a classroom management plan and check what is working and what is not working for that particular group of students. PSTs need to tailor different skills towards different groups of students because the same sets of skills do not work for every group. Ferber and Nillas (2010) emphasize the importance of teacher education program creating opportunities for PST's to learn and experience a variety of methods about classroom management.

\section{Science Content Knowledge}

Science content knowledge is very important for the teachers to design effective science lessons, use different instructional strategies, and help students understand the science concepts in the classroom. Grant and Gillette (2006) posit that "Effective teachers need depth and breadth of content knowledge" (p. 295). Especially in the case of PSTs, who are novices in the classrooms, adequate science content knowledge boosts their confidence and helps them stand face to face with various challenges. Lee, Hart, Cuevas, and Enders (2004) emphasize the importance of content knowledge as a prerequisite to teacher inquiry successfully. This shows that PSTs need to master the subject before teaching it to students. Lack of content knowledge enhances the persistence of misconceptions for students and teachers as well. Luera, Moyer, and Everett (2005) recognized that "Science content knowledge is fundamental in designing 5E inquiry-based lessons" (p. 22). In this study, all the students had taken a required science course which covered the basics of physical, biological and earth sciences. However, as shown in the results, many students were not very comfortable with thescience content. This is in 
line with Yoon, Joung, and Kim (2011) as they believed many PSTs lack science content knowledge even after taking many science content courses. The results of this study suggest that more content courses are required for PSTs. It might be important for PSTs to take more than one content course to master the basics in each of the science taught at elementary.

\section{Disjunction between Theory and Practice}

In teacher education programs, PSTs are usually surprised by the idea of how demanding the teaching profession could be and how it is different from what they expected (Kagan, 1992). When PSTs enter the K-12 classrooms and try to implement what they have learned in teacher education programs, they face many hurdles. Schulz and Mandzuk (2005) report what pre-service teachers called the "disjunction" between what they learned in university and what actually happens in the classrooms. One of the participants (teacher candidate) said, "I assumed that the theory we're taking here at the university would transfer over into practice in the school, things like teacher as researcher that just isn't happening" (p. 322). Mapping this to our study, we can say that, PSTs were rigorously trained to apply the 5E inquiry model. They implemented it in their university classroom, but they rarely observed their cooperating in-service teachers applying it. Therefore, convincing PSTs that they need to change the way they teach all the time will be hard. Some PST referred to this disjunction between theory and practice in the interviews by indicating that that K-12 classrooms are very different from the college classrooms. For instance, P-28 in his interview said "it is just lot different when you actually have young kids who are trying to work with you versus when we are teaching to peers." The in-service teacher also posited that colleges only teach ideals and not real-life situations and PSTs find fitting those ideals into K-12 classrooms difficult. She indicated that mentors in the universities should create more opportunities for the PSTs to observe the in-service teachers' practices in K-12 classrooms, and develop good rapport with them. This allows for better communication and the PST's can ask about why the in-service teacher is preferring one teaching method over another. Ferber and Nillas (2010) posited that "Cooperative teachers, university supervisors, and teacher education programs all play a role in helping the pre-service teacher mold a functional understanding during the student teaching experience" (p. 66). This means that there is a responsibility on teacher education programs to seriously revisit how to map the theory and practice. Teacher education programs need to support the inquiry practices they preach and practice in their class to move to becoming integral practice in the field classrooms.

\section{Implications for Teacher Education Programs}

Help PSTs acquire strong content knowledge. One of the main results of this study is that PSTs face a challenge with the content knowledge. As a result, teacher education programs can help PSTs acquire strong content knowledge by offering more science content courses and some interdisciplinary courses. We recommend that more opportunities should be available for PSTs to reinforce content knowledge. This can happen through formal channels such as creating more specialized science courses that teach PSTs through inquiry. It can also happen through creating credit hours where PSTs can intern in museums, zoos, or botanical gardens and learn about science content and how to interact with young children in informal settings.

Create opportunities for PSTs to interact with the cooperative teachers.

Cooperative teachers/field placement teachers play an important role in carving the PSTs' career of teaching. For example, Graham (2006) in her study mentioned that the cooperative teacher, who guides and supports, is one of the important component for success of the intern (teacher candidate). Teacher education programs could design a course in which PSTs receive opportunities to: 1) plan and teach a whole science unit (usually 4 to 6 lessons) in collaboration with cooperative teachers, 2) hold meetings with the cooperative teachers on a weekly basis to obtain feedback and increase the communication and rapport. Knowing that not all cooperative teachers are willing to spend this time with PST's, teacher education programs should take the responsibility of rewarding the cooperative 
teachers in a timely manner. Cooperative teachers could be rewarded monetarily (cash awards, quarterly bonus, etc.), non-monetarily (time-off from work, flexible schedules, etc.) or by professional recognition (Teacher of the Year, Employee of the Month, etc.). Rewards encourage cooperative teachers to maintain cordial relationship with the PSTs and share their knowledge and expertise.

\section{References}

Abd-El-Khalick, F., Boujaoude, S., Duschl, R., Lederman, N. G., Mamlok-Naaman, R., Hofstein, A., ...Tuan, H. (2002). Inquiry in science education: International perspectives. Science Education, 88(3), 397-419.

Ball, D. L. (2000). Bridging practices: Intertwining content and pedagogy in teaching and learning to teach. Journal of Teacher Education, 51(3), 241-247.

Black, K. (2004). Science in the trenches: An exploration of four pre-service teachers' first attempts at teaching science in the classroom. International Journal of Science and Mathematics Education, 2, 25-44.

Bybee, R. W. (2015). The BSCS 5E Instructional Model: Creating Teachable Moments. Arlington, VA: National Science Teachers Association Press.

Bybee, R., Taylor, J., Gardener, A., Scotter, P. V., Powell, C. J., Westbrook, A., \& Landes, N. (2006). The BSCE 5e instructional model: Origins and effectiveness. Retrieved from http://bscs.org/sites/default/files/_legacy/BSCS_5E_Instructional_ModelFull_Report.pdf.

Corbin, J. M., \& Strauss, A. (2014). Basics of qualitative research: Techniques and procedures for developing grounded theory. Thousand Oaks, CA: Sage Publications, Inc.

Crawford, B. A. (1999). Is it realistic to expect a pre-service teacher to create an inquiry-based classroom? Journal of Science Teacher Education, 10, 175-194.

Davis, E., Petish, D., \& Smithey, J. (2006). Challenges new science teacher's face. Review of Educational Research. 76(4), 607-651.

Driver, R., Guesne, E., \& Tiberghien, A. (1985). Children's ideas in science. Milton Keynes, PA: Open University Press.

Fantilli, R. D., \& McDougall, D. E. (2009). A study of novice teachers: Challenges and supports in the first years. Teaching and Teacher Education, 25(6), 814-825.

Fazio, X., Melville, W., \& Bartley, A. (2010). The problematic nature of the practicum: A key determinant of pre-service teachers' emerging inquiry-based science practices. Journal of Science Teacher Education, 21, 665-681.

Ferber, T., \& Nillas, L. A. (2010). Through the eyes of student teachers: Successes and challenges in field teaching experiences. National Teacher Education Journal, 3(2), 61-85.

Gerber, B. L., Cavallo A. M. L., \& Marek E. A. (2001). Relationships among informal learning environments, teaching procedures and scientific reasoning ability, International Journal of Science Education, 23(5), 535-549.

Giebelhaus, C. R., \& Bowman, C. L. (2002).Teaching mentors: Is it worth the effort? The Journal of Education Research, 95(4), 246254.

Graham, B. (2006). Conditions for successful field experiences: Perceptions of cooperating teachers. Teaching and Teacher Education, 22(8), 1118-1129.

Grant, C. A., \& Gillette, M. (2006). A candid talk to teacher educators about effectively preparing teachers who can teach everyone's children. Journal of Teacher Education, 57(3), 292-299.

Hanuscin, D., \& Lee, M. H. (2008). Using the learning cycle as a model for teaching the learning cycle to preservice elementary teachers. Journal of Elementary Science Education, 20(2), 51-66.

Kagan, D. M. (1992). Professional growth among preservice and beginning teachers. Review of Educational Research, 62(2), 129169.

Kang, E. J. S., Bianchini, J. A., \& Kelly, G. J. (2013). Crossing the border from science student to science teacher: Preservice teachers' views and experiences learning to teach inquiry. Journal of Science Teacher Education, 24, 427-447.

Karplus, R., Thier, H., Lawson, C., Knoll, R., \& Montgomery, M. (1967). Science curriculum improvement study. Chicago, IL: Rand McNally.

Lawson, A. E., Abraham, M. R., \& Renner, J. W. (1989). A theory of instruction: Using the learning cycle to teach science concepts and thinking skills. National Association for Research in Science Teaching. Cincinnati, $\mathrm{OH}$

Lee, O., Hart, J. E., Cuevas, P., \& Enders, C. (2004). Professional development in inquiry-based science for elementary teachers of diverse student groups. Journal of Research in Science Teaching, 41(10), 1021-1043.

Luera, G. R., Moyer, R. H., \& Everett, S. A. (2005). What type and level of science content knowledge of elementary education students affect their ability to construct an inquiry-based science lesson? Journal of Elementary Science Education, 17(1), $12-25$.

McDonnough, J. T., \& Matkins, J. J. (2010). The role of field experience in elementary preservice teachers' self-efficacy and ability to connect research to practice. School Science and Mathematics, 110(1), 13-23.

Meador, G. (1988). The Piagetian Intelligence Model and the Learning Cycle. Retrieved from http://www.bhsphysics.org/papers/

Sadler, T. D. (2006). “I won't last three weeks": Preservice science teachers reflect on their student-teaching experiences. Journal of Science Teacher Education, 17, 217-241.

Schulz, R., \& Mandzuk, D. (2005). Learning to teach, learning to inquire: A 3-year study of teacher candidates' experiences. Teaching and Teacher Education, 21, 315-331.

Sickel, A. J., \& Friedrichsen, P. (2015). Beliefs, practical knowledge, and context: A longitudinal study of a beginning biology teacher's 5E unit. School Science and Mathematics, 115(2), 75-87

Walbert, D. (n.d.). The learning cycle. Retrieved from http://www.learnnc.org/lp/pages/663 
Windschitl, M., \& Thompson, J. (2006). Transcending simple forms of school science investigations: The impact of pre-service instruction of model-based inquiry. American Educational Research Journal, 43(4), 783-835.

Yoon, H.-G., Joung, Y. J., \& Kim, M. (2012). The challenges of science inquiry teaching for pre-service teachers in elementary classrooms: Difficulties on and under the scene. Research in Science Education, 42, 589-608.

Zembal-Saul, C., Starr, M., \& Krajcik, J. S. (1997). Preparing elementary science teachers: An application of research and practice. Paper presented at the Annual Meeting of the National Association for Research in Science Teaching (NARST), Chicago, Illinois. 


\section{Supplementary Materials}

\section{Appendix A}

Pre-course Survey: 1

Name: $P-35$

1. How many science courses did you take in high school? What are they?

A: 3 - Biology, Chemistry, Physics

2. Have you taken any science courses before this semester at TCU? What are they?

A: Yes - Biology, Natural Disasters \& Failures

3. What grade level are you planning to teach?

A: $3^{\text {rd }}$ and $4^{\text {th }}$ grade

4. What do you expect to learn in this course?

A: How to successfully teach students different content areas of science and to gain more skills and teaching strategies.

5. In your opinion what is the best way to teach science?

A: With hands-on activities and detailed instructions.

6. Give an example of when you learned a science topic well and why? Explain in detail.

A: I really enjoyed learning about chemical reactions in high school because it was very detailed and hands-on and I could see the content I was learning in front of my face.

7. Have you heard about inquiry? In your opinion, what is it?

A: Not specifically, but maybe asking questions?

8. Do you think inquiry has advantages? If yes, what are they? If no, why not?

A: Yes, I think it is important for students to ask questions when they are confused. Questions help students gain insight and knowledge about a topic.

9. Do you think inquiry has challenges? Why or why not?

A: No

10. What type of challenges do you think inquiry has?

A: I am not sure. 


\section{Appendix B}

Post-course Survey:

Name: P-35

1. Which grade level did you teach?

A: The two grade levels my partner and I observed this semester were $3^{\text {rd }}$ grade at Dallas Park Elementary School and $5^{\text {th }}$ grade at Westcliff Elementary School. The grade level we taught in the field was $5^{\text {th }}$ grade.

2. What did you learn in this course?

A: This semester, I learned that science is not just experiments, but explaining and making connections. The $5 \mathrm{E}$ model is a great tool to use when planning a lesson. I also learned that it is important to use different ways to approach a concept so students get a better understanding.

3. In your opinion what is the best way to teach science?

A: In my opinion, the best way to teach science is by combining hands-on activities with straight-up content (PowerPoints, handouts, etc.). By utilizing multiple techniques, it gives students various ways to understand and absorb the information presented to them. Hands-on activities are so important to incorporate in science lessons. It gives students the opportunity to really figure out the concept for themselves, and allows them to apply it to a real life situation in front of them. It is obviously important to present the students with the information via note taking, etc. because it gives them straightforward information that they can refer back to. Having a balance between the two is important and a great way to teach science.

4. Give an example of when you learned a science topic well and why? Explain in detail.

A: One concept that I learned a lot about in this course this year was the concept of natural selection. When we learned about it, we did a hands-on activity with varying sizes of clips. At our tables, we were supposed to 'eat' the 'food' provided, and each beak size had to get a different amount of calories in order to survive and/or reproduce. This really showed the concept of natural selection because I could see that when a certain food runs out or there are other species that survive easier or are stronger, others will die out. We then review different concepts and vocab words, and connected it to other real-life examples. This lesson was extremely beneficial to me as both a future teacher and a pretend student. I was able to put myself in the shoes of a student and really see how important it is to use activities to teach a concept. I now remember how my beak size got killed off because there was not enough food that I was able to catch-the perfect specific explanation for natural selection.

5. What is inquiry in your opinion?

A: In my opinion, inquiry is a process of gaining an understanding of the scientific world through questioning and wonder.

6. Do you think inquiry has advantages? If yes, what are they? If no, why not?

A: There are definitely advantages to inquiry. Inquiry allows you to question different concepts, and probe further thinking. It also allows you to wonder about why some things are a certain way, and how and why some things work. There are a lot of possibilities and opportunities with inquiry, and it allows a person to gain a deep and detailed understanding of a concept by asking questions and fulfilling their wonder. You can find out solutions and answers to questions by using inquiry.

7. Do you think inquiry has challenges? Why or why not?

A: There are also disadvantages to inquiry as well. There are disadvantages because, like almost anything in life, inquiry is not a flawless concept, and there is bound to be something that does not work perfectly.

8. What type of challenges do you think inquiry has? 
A: One of the disadvantages of inquiry is that sometimes, a person might not be fully satisfied by the answer they receive from using inquiry. Other times, a person might be confused by the findings they receive when using inquiry to understand a concept. A person might also receive more than one outcome, which can be frustrating and unwanted. Inquiry does not always promise an answer or an understanding, so a disadvantage is that there might not be one as well. 


\section{Appendix C}

Interview Questions

Name: P-28

Interviewer: Which grade level did you teach in your field experience?

Interviewee: I was in both second grade and fifth grade.

Interviewer: What was your best experience while taking this course?

Interviewee: I think probably teaching like coming up with a lesson plan and doing in the class just because I don't know it was really interesting to see like what worked in the class with the big class because when we are in the field, most of the times teachers don't let you to take over the entire class. They only want you to take small group, so you know its lot different working with a small group than a large class. So, I really enjoyed that part of the course.

I really enjoyed doing experiments too at the beginning because they help you get new ideas of how to do stuff in the class and stuff like that. I saw like what really works, what might be changed. I know when we were doing like the density and stuff like that may be do some stuff differently with different grade levels. It was just interesting to see how you modify it for any grade level.

Interviewer: After your field experiences and taking this course, what do you think are some of the challenges for teaching science in schools?

Interviewee: I think the biggest one probably is trying to find something that is fun for the kids doing also can get across the content at the same time. Just try to come up with like a good experiment and try to know stuff like before-hand that happens and try to like prepare for that because I know sometimes like something can go wrong that really unexpected. When we are doing lesson in the field, we did give them magnets and they were sticking magnets on the computer. We were like No! no! don't really do that stuff like that but I don't want to hinder them exploring because the point was to see what magnets would stick around the room. Because we started out with a little bag, there is some stuff in there that was magnetic. We want them to take what we talked about with those go outside and find it. So kind of hard preparing and stuff like that in the field.

Interviewer: Did you face any challenges while using the $5 \mathrm{E}$ model of instruction? If yes, what are they?

Interviewee: With the 5E model, the Extend part, I feel like that it was lot extra stuff, I just thought like sometimes the extend thing was not necessary. Sometimes I could like put as little as possible because I thought I got everything I wanted to do with elaborate and explore.

Only these were challenges using $5 \mathrm{E}$ model that's because I really like $5 \mathrm{E}$ because it really helps you map everything out, so it is really good to plan. She gave us a lesson plan or model lesson plan which was not as detailed, it was basically do this and the 5E model is like you need to have clearly how to introduce lesson and work our way into. So, uh! But the thing is, I don't know usually if you do it over a period of time, because within a one day period it's really hard to fit that entire 5E model in it. When we are teaching our lesson in the class. We kind of went over a time a little bit I noticed because it was so much stuff to do and some activities require a longer time, so the $5 \mathrm{E}$ model works best if you have multiple days to do it over within one day period. May be because if you have a longer class periods, we only had $\mathbf{3 0}$ minutes. I am sure if we had $\mathbf{5 0}$ minutes it would be good. But I feel like in lower grades it's better to do over a period of time, it could be over whelming to some of the students.

Interviewer: In your opinion what can help you in overcoming the challenges of teaching with the 5E model?

Interviewee: The biggest thing is we having more time to think and another thing I think that helps you is if I was able to collaborate with the teacher and tell ok! Here it is! I could not do it. Because for a while e- mail we were trying to send our teacher was not working. Stuff like that. It is really hard for them to like, they taught a lot, so I wanted them to see like you know if it is like 
first year teacher, are you still like getting into it is to have veteran teacher look it over and just like give some pointers on like change everything be like ok! This is good, Kind of let them, if you like see a mistake, let them go through that and let them experience it. That way for the next time, like still give them points and stuff and then afterwards say this is what I could have done in this situation. I feel like the collaboration is the most important part. It is always best to have as many people can put on what you are trying to teach the kids.

Interviewer: Share your experiences from your field experience during which you felt students learnt better using the 5Emodel.

Interviewee: From what I saw that the kids like they get most is when they work in groups. Individually, they would just talk and do all that kind of stuff. When worked in groups sometimes they might go off task but ultimately they got to the goal lot faster and it is easy for them to understand. If one student doesn't understand something another students can help him. So kind of like self-teaching so you don't have to be on top every single kid, you have little breathing room.

Interviewer: Share the experiences of the challenges of using the $5 \mathrm{E}$ in the field.

Interviewee: Just working with individual kids is the hardest thing. The struggle when they don't understand it and you are trying to get it across and you are trying to reword like how you say stuff I think that's more difficult. When I was trying to teach Math lesson they found way to do these fractions but I understand that you guys understand that way but let's try to find another way. When I watched the video I realized maybe I should reword that differently. So, actually when you are in the field talking with the kids it is important how you word everything and communicate ideas in a way each kid can understand.

Interviewer: Was the 5E more challenging the field than in peer teaching? Why or why not?

Interviewee:I felt it was more challenging at the field because, it's just lot different when you actually have young kids who is trying to work with you because they are trying to learn it versus when we are teaching to peers in the classroom everyone knows we did layers of the earth so we are just shrug through the lesson. When I tried to explain how magnets work it took a lot longer so that is just more difficult. It is just because of area between intellects.

Interviewer: Give an example of some of the pros and cons of the 5E Model?

Interviewee: The biggest pro like I said earlier is it really helps you map it out and helps you become thorough with it. As you know with the laboratory you have to go like go on with it. Some stuff with extend, sometimes it works well and sometimes its jut like extra fat, which is like we don't need that just shave that off. 


\section{Appendix D}

Peer Teaching Lesson Plans:

Name: PSTM-25, PSTM-18 (High)

Title: Complete and Incomplete Metamorphosis.

Objective: For the students to be able to define metamorphosis and differentiate between complete and incomplete metamorphosis

Table E4

\begin{tabular}{|c|c|c|c|}
\hline Phase & Criteria & Grade & Comments \\
\hline Engage & $\begin{array}{l}\text { - Have a clear objective that students will } \\
\text { learn after the lesson }(4 / 5) \\
\text { - Interesting introduction }(4 / 5)\end{array}$ & $8 / 10$ & $\begin{array}{l}\text { Very interesting } \\
\text { engagement and clear } \\
\text { objective. Book reading } \\
\text { could have been more } \\
\text { creative to engage } \\
\text { students. }\end{array}$ \\
\hline Explore & $\begin{array}{l}\text { - } \quad \text { Clear instructions of the activities (4/5) } \\
\text { - Organized way of recording data and } \\
\text { analyzing it }(4 / 5)\end{array}$ & $8 / 10$ & $\begin{array}{l}\text { Instructions could have } \\
\text { been better and could } \\
\text { have asked students to } \\
\text { make note of the Venn } \\
\text { diagram in their } \\
\text { journals. Estimated } \\
\text { unrealistic time slot. }\end{array}$ \\
\hline Explain & $\begin{array}{l}\text { - Asking students CRITICAL questions that } \\
\text { can lead them to the desired scientific } \\
\text { explanation (4/5) } \\
\text { Mentioning how you will lead the } \\
\text { discussion at different stages of the lesson } \\
\text { and how you will relate the hands on } \\
\text { (investigation) to the minds on (scientific } \\
\text { explanation)(4.5/5) }\end{array}$ & $8.5 / 10$ & $\begin{array}{l}\text { Did not have any } \\
\text { critical questions but } \\
\text { the activity was very } \\
\text { interesting and helpful. }\end{array}$ \\
\hline Elaborate & $\begin{array}{l}\text { Mentioning one or two examples of how } \\
\text { you will expand on what they have } \\
\text { learned by mentioning other examples or } \\
\text { relating it to real life }\end{array}$ & $8.5 / 10$ & $\begin{array}{l}\text { Good way to elaborate } \\
\text { the lesson. Before } \\
\text { asking students to do } \\
\text { so, could have shown } \\
\text { examples. }\end{array}$ \\
\hline Evaluate & $\begin{array}{l}\text { Having an assessment question that is } \\
\text { specific to the scientific content you } \\
\text { taught. The question has to be clearly } \\
\text { written for students to understand it (4/5) } \\
\text { - Having an sample answer to your specific } \\
\text { question and how you will grade if you } \\
\text { were to give it to the students }(4 / 5)\end{array}$ & $8 / 10$ & $\begin{array}{l}\text { Very good assessment } \\
\text { activity but did not } \\
\text { mention the grading } \\
\text { criteria. }\end{array}$ \\
\hline Total & & $41 / 50$ & \\
\hline
\end{tabular}

Name: PSTW-28, PST-32 (Medium)

Title: Structure of the Earth

Objective: The student is expected to: build a model to illustrate the structural layers of Earth, including the inner core, outer core, mantle, crust, asthenosphere, and lithosphere. 
Table E5

\begin{tabular}{|c|c|c|c|}
\hline Phase & Criteria & Grade & Comments \\
\hline Engage & $\begin{array}{l}\text { - Have a clear objective that students will } \\
\text { learn after the lesson }(4 / 5) \\
\text { - } \quad \text { Interesting introduction }(4 / 5)\end{array}$ & $8 / 10$ & $\begin{array}{l}\text { Clear objective and } \\
\text { interesting } \\
\text { engagement. }\end{array}$ \\
\hline Explore & $\begin{array}{l}\text { - } \quad \text { Clear instructions of the activities }(3 / 5) \\
\text { - } \text { Organized way of recording data and } \\
\text { analyzing it }(3 / 5)\end{array}$ & $7 / 10$ & $\begin{array}{l}\text { Ask questions which } \\
\text { push students to think } \\
\text { and compare what they } \\
\text { modelled and observed } \\
\text { in the video/ slides. }\end{array}$ \\
\hline Explain & $\begin{array}{l}\text { - Asking students CRITICAL questions that } \\
\text { can lead them to the desired scientific } \\
\text { explanation (4.5/5) } \\
\text { Mentioning how you will lead the } \\
\text { discussion at different stages of the lesson } \\
\text { and how you will relate the hands on } \\
\text { (investigation) to the minds on (scientific } \\
\text { explanation)(4.5/5) }\end{array}$ & $9 / 10$ & $\begin{array}{l}\text { Very good questions. } \mathrm{T} \\
\text { charts, discussions and } \\
\text { making flip book } \\
\text { altogether seems } \\
\text { unrealistic with the } \\
\text { time they mentioned } \\
\text { but, good scientific } \\
\text { explanation if } \\
\text { implemented as } \\
\text { planned. }\end{array}$ \\
\hline Elaborate & $\begin{array}{l}\text { - Mentioning one or two examples of how } \\
\text { you will expand on what they have } \\
\text { learned by mentioning other examples or } \\
\text { relating it to real life }\end{array}$ & $6 / 10$ & $\begin{array}{l}\text { Good video to } \\
\text { elaborate the lesson } \\
\text { and good questions. }\end{array}$ \\
\hline Evaluate & $\begin{array}{l}\text { - Having an assessment question that is } \\
\text { specific to the scientific content you } \\
\text { taught. The question has to be clearly } \\
\text { written for students to understand it }(0 / 5) \\
\text { Having an sample answer to your specific } \\
\text { question and how you will grade if you } \\
\text { were to give it to the students }(5 / 5)\end{array}$ & $5 / 10$ & $\begin{array}{l}\text { Did not mention } \\
\text { questions but had } \\
\text { grading criteria. That is } \\
\text { too much information } \\
\text { for one lesson. }\end{array}$ \\
\hline Total & & $36 / 50$ & \\
\hline
\end{tabular}

Name: PSTM-23, PSTM-10 (Low)

Title: Plate Tectonics

Objective:The objective of this lesson is for students to understand how tectonic plates interact with each other at their boundaries.

Table E6

\begin{tabular}{|l|c|c|c|}
\hline Phase & \multicolumn{1}{|c|}{ Criteria } & Grade & \multicolumn{1}{c|}{ Comments } \\
\hline Engage & $\bullet \begin{array}{l}\text { Have a clear objective that students will } \\
\text { learn after the lesson (2.5/5) } \\
\text { Interesting introduction (2.5/5) }\end{array}$ & $5 / 10$ & $\begin{array}{l}\text { Good engagement and } \\
\text { clear objective but have } \\
\text { ways to assess students } \\
\text { for their prior } \\
\text { knowledge about the } \\
\text { topic rather than } \\
\text { jumping directly into } \\
\text { the topic. Unrealistic } \\
\text { time slot for this phase. }\end{array}$ \\
\hline Explore & - Clear instructions of the activities (4/5) & $4 / 10$ & Instructions could have \\
\hline
\end{tabular}




\begin{tabular}{|c|c|c|c|}
\hline & $\begin{array}{l}\text { - Organized way of recording data and } \\
\text { analyzing it }(0 / 5)\end{array}$ & & $\begin{array}{l}\text { been clearer. No } \\
\text { organized way of } \\
\text { recording data. }\end{array}$ \\
\hline Explain & $\begin{array}{l}\text { - Asking students CRITICAL questions that } \\
\text { can lead them to the desired scientific } \\
\text { explanation (_2.5/5) } \\
\text { - Mentioning how you will lead the } \\
\text { discussion at different stages of the lesson } \\
\text { and how you will relate the hands on } \\
\text { (investigation) to the minds on (scientific } \\
\text { explanation)(_1.5/5) }\end{array}$ & $4 / 10$ & $\begin{array}{l}\text { Could have asked more } \\
\text { questions which push } \\
\text { students thinking about } \\
\text { the plate movements. } \\
\text { No ways mentioned to } \\
\text { related hands-on and } \\
\text { minds-on parts of the } \\
\text { lesson. Failed to discuss } \\
\text { the observations after } \\
\text { experiments }\end{array}$ \\
\hline Elaborate & $\begin{array}{l}\text { Mentioning one or two examples of how } \\
\text { you will expand on what they have } \\
\text { learned by mentioning other examples or } \\
\text { relating it to real life }\left(\_/ 10\right)\end{array}$ & $4 / 10$ & $\begin{array}{l}\text { Ask the students to } \\
\text { give some examples } \\
\text { rather than just } \\
\text { showing them } \\
\text { examples. }\end{array}$ \\
\hline Evaluate & $\begin{array}{l}\text { Having an assessment question that is } \\
\text { specific to the scientific content you } \\
\text { taught. The question has to be clearly } \\
\text { written for students to understand it (5/5) } \\
\text { - Having an sample answer to your specific } \\
\text { question and how you will grade if you } \\
\text { were to give it to the students }\left(\_2 / 5\right)\end{array}$ & $7 / 10$ & $\begin{array}{l}\text { Good way to assess, no } \\
\text { grading criteria }\end{array}$ \\
\hline Total & & $24 / 50$ & \\
\hline
\end{tabular}




\section{Appendix E}

Peer teaching Evaluation Criteria:

Name: PSTW-44, PSTW-31 (High)

Title: Parts of a food web

Objective: Students will identify parts of the food web.

Table D1

\begin{tabular}{|c|c|c|}
\hline Criteria & Points & Comments \\
\hline $\begin{array}{l}\text { Was the objective of the lesson clear and } \\
\text { did you start by telling us this objective }\end{array}$ & $5 / 5$ & $\begin{array}{l}\text { Yes! Objective of the lesson was clear and } \\
\text { they did start the lesson by saying the } \\
\text { objective. }\end{array}$ \\
\hline $\begin{array}{l}\text { Did you have an interesting and } \\
\text { engaging introduction }\end{array}$ & $5 / 5$ & $\begin{array}{l}\text { They started with the idea and built on it } \\
\text { from students' prior knowledge which was } \\
\text { very interesting. } \\
\text { They asked few questions: } \\
\text { Q1: What is food web? Name its parts } \\
\text { (ANSWERS: animals are connected, layered) } \\
\text { Q2: What do you remember from the food } \\
\text { web lesson Dr. H taught us? } \\
\text { Q3: Can you give examples of three animals } \\
\text { in food web. }\end{array}$ \\
\hline $\begin{array}{l}\text { Did you give clear instructions for the } \\
\text { hands on activities }\end{array}$ & $5 / 5$ & $\begin{array}{l}\text { Gave clear instructions and the timer on the } \\
\text { PPT was a great idea. The PPT was well } \\
\text { organized. }\end{array}$ \\
\hline $\begin{array}{l}\text { Were you well prepared for the lesson, } \\
\text { did you have all the materials you } \\
\text { needed }\end{array}$ & $5 / 5$ & Excellent preparation! \\
\hline $\begin{array}{l}\text { Were the activities purposeful in } \\
\text { investigating the concept you want us } \\
\text { to learn (hands on part) }\end{array}$ & $5 / 5$ & $\begin{array}{l}\text { Very purposeful activities, and the students } \\
\text { enjoyed the creative elements of the activity } \\
\text { Activity: Be an explorer and write an article } \\
\text { for National Geographic. Students were } \\
\text { supposed to pick an animal and make their } \\
\text { own masks, decide which order they need to } \\
\text { go in food chain and, divide the Kilocalories. } \\
\text { This activity was good as students had fun } \\
\text { making masks, at the same time they tried to } \\
\text { discover who eats whom. } \\
\text { Good explanation about the unit (kilo } \\
\text { calories) }\end{array}$ \\
\hline $\begin{array}{l}\text { Were the discussions during and after } \\
\text { the activities purposeful in teaching us } \\
\text { about the concept }\end{array}$ & $3.5 / 5$ & $\begin{array}{l}\text { The questions were good, but there is a need } \\
\text { for the discussions of how and why energy is } \\
\text { lost. They failed to discuss how that affects } \\
\text { the ecosystem (energy is not recycled and } \\
\text { we're dependent on the sun for energy). }\end{array}$ \\
\hline $\begin{array}{l}\text { Did you have an interesting and } \\
\text { engaging assessment question that } \\
\text { pushed our thinking of the concept }\end{array}$ & $4 / 5$ & $\begin{array}{l}\text { They had good assessment, but I would try to } \\
\text { have a question that can push the thinking } \\
\text { further. }\end{array}$ \\
\hline $\begin{array}{l}\text { Did we learn the appropriate and } \\
\text { adequate scientific explanation from } \\
\text { this lesson }\end{array}$ & $3.5 / 5$ & $\begin{array}{l}\text { They touched upon a crucial idea Energy } \\
\text { Pyramid, but they need to make that explicit } \\
\text { as to why this happens. Also there is a need }\end{array}$ \\
\hline
\end{tabular}




\begin{tabular}{|c|c|c|}
\hline & & $\begin{array}{l}\text { to show the importance of this to the } \\
\text { ecosystem (energy is never recycled so we } \\
\text { need a constant supply, if no sun, we all die). }\end{array}$ \\
\hline $\begin{array}{l}\text { Did you have good eye contact, loud } \\
\text { enough voice and communicated } \\
\text { enthusiasm to the class? }\end{array}$ & $5 / 5$ & $\begin{array}{l}\text { They had a very approachable and fun } \\
\text { personality in the class. }\end{array}$ \\
\hline $\begin{array}{l}\text { Did you use different instructional } \\
\text { strategies and media sources? }\end{array}$ & $5 / 5$ & $\begin{array}{l}\text { They did not use different media sources but } \\
\text { used different instructional strategies. }\end{array}$ \\
\hline TOTAL & $46 / 50$ & \\
\hline Timing: & $\begin{array}{l}32 \\
\text { minutes }\end{array}$ & \\
\hline
\end{tabular}

Name: PSTW-30, PSTW-53 (Medium)

Title: Properties of matter

Objective: To identify three states of matter and distinguish them.

Table D2

\begin{tabular}{|c|c|c|}
\hline Criteria & Points & Comments \\
\hline $\begin{array}{l}\text { Was the objective of the lesson clear and } \\
\text { did you start by telling us this objective }\end{array}$ & $1.5 / 5$ & $\begin{array}{l}\text { The objective was not clear. They said, we will } \\
\text { talk about matter but were not clear what the } \\
\text { objective was, what exactly about matter. }\end{array}$ \\
\hline $\begin{array}{l}\text { Did you have an interesting and } \\
\text { engaging introduction }\end{array}$ & $4 / 5$ & $\begin{array}{l}\text { Students were asked to imagine that they } \\
\text { were in the ice hotel and they gave cards with } \\
\text { solid, liquid and gas written. Asked students } \\
\text { to say what ice block is? Students answered } \\
\text { solid. For which they gave positive } \\
\text { reinforcement and explained about solids. } \\
\text { Continued the activity with liquid, and gas. } \\
\text { I also liked how they asked students what } \\
\text { matter is, but students ideas such as "stuff" or } \\
\text { "something that matter" were not explored. }\end{array}$ \\
\hline $\begin{array}{l}\text { Did you give clear instructions for the } \\
\text { hands on activities }\end{array}$ & $4.5 / 5$ & $\begin{array}{l}\text { Clear instructions, PPT was very well } \\
\text { organized. }\end{array}$ \\
\hline $\begin{array}{l}\text { Were you well prepared for the lesson, } \\
\text { did you have all the materials you } \\
\text { needed }\end{array}$ & $4.5 / 5$ & Well prepared. \\
\hline $\begin{array}{l}\text { Were the activities purposeful in } \\
\text { investigating the concept you want us } \\
\text { to learn (hands on part) }\end{array}$ & $4 / 5$ & $\begin{array}{l}\text { Activity: Students were given bag with } \\
\text { pictures like gasoline, books, rain, steam, } \\
\text { rocket exhaust and asked to classify using a } \\
\text { table(under solid, liquid, gas) } \\
\text { They made students explore with pictures, } \\
\text { think about the concept of solids, liquids and } \\
\text { matter. } \\
\text { They asked students the criteria and their } \\
\text { explanation for categorizing pictures. It was } \\
\text { very interesting to see students come up with } \\
\text { explanations. }\end{array}$ \\
\hline $\begin{array}{l}\text { Were the discussions during and after } \\
\text { the activities purposeful in teaching us } \\
\text { about the concept }\end{array}$ & $3.5 / 5$ & $\begin{array}{l}\text { Students asked certain questions (Is cloud } \\
\text { gas? They answered saying yes as molecules } \\
\text { are more spread out) } \\
\text { I think your discussion needs to focus on the }\end{array}$ \\
\hline
\end{tabular}




\begin{tabular}{|c|c|c|}
\hline & & $\begin{array}{l}\text { strategy of distinguishing states of matter by } \\
\text { explaining molecular representation of solids, } \\
\text { liquids, and gases. }\end{array}$ \\
\hline $\begin{array}{l}\text { Did you have an interesting and } \\
\text { engaging assessment question that } \\
\text { pushed our thinking of the concept }\end{array}$ & $2.5 / 5$ & $\begin{array}{l}\text { Besides assessing formatively and asking } \\
\text { questions, I did not see any scenario or } \\
\text { activity in the end that assessed their } \\
\text { understanding. They could have been creative } \\
\text { with this part of the lesson. }\end{array}$ \\
\hline $\begin{array}{l}\text { Did we learn the appropriate and } \\
\text { adequate scientific explanation from } \\
\text { this lesson }\end{array}$ & $2.5 / 5$ & $\begin{array}{l}\text { Their objective was to distinguish solid liquid } \\
\text { and gas, but the criteria were not emphasized, } \\
\text { and the relationship to the molecules was not } \\
\text { explored. This leaves students with some } \\
\text { confusion of how we can distinguish solids } \\
\text { from liquids from gases. }\end{array}$ \\
\hline $\begin{array}{l}\text { Did you have good eye contact, loud } \\
\text { enough voice and communicated } \\
\text { enthusiasm to the class? }\end{array}$ & $4 / 5$ & $\begin{array}{l}\text { PSTW-30, you act things out with a lot of } \\
\text { expression and kids will LOVE that in the } \\
\text { classrooms. PSTW-53, I would just add a bit } \\
\text { more enthusiasm when you teach alone }\end{array}$ \\
\hline $\begin{array}{l}\text { Did you use different instructional } \\
\text { strategies and media sources? }\end{array}$ & $4 / 5$ & Yes they did but no media sources. \\
\hline Timing & $\begin{array}{l}32 \mathrm{minu} \\
\text { tes }\end{array}$ & \\
\hline TOTAL & $35 / 50$ & \\
\hline
\end{tabular}

Name: PSTM-19, PSTM-7 (Low)

Title: Understanding Animal Cells

Objective: Students will identify parts of the cell and its functions.

Table D3

\begin{tabular}{|c|c|c|}
\hline Criteria & Points & Comments \\
\hline $\begin{array}{l}\text { Was the objective of the lesson clear and } \\
\text { did you start by telling us this objective }\end{array}$ & $5 / 5$ & $\begin{array}{l}\text { Clear objective, they did start the lesson by } \\
\text { telling the objective. }\end{array}$ \\
\hline $\begin{array}{l}\text { Did you have an interesting and } \\
\text { engaging introduction }\end{array}$ & $3.5 / 5$ & $\begin{array}{l}\text { Questions: Difference between plant and } \\
\text { animal cell? Some functions of animal cell? } \\
\text { Parts of animal cell? } \\
\text { They had picture of plant and animal cell and } \\
\text { told differences between them. Asking } \\
\text { students to find differences could have made } \\
\text { a more engaging introduction }\end{array}$ \\
\hline $\begin{array}{l}\text { Did you give clear instructions for the } \\
\text { hands on activities }\end{array}$ & $3.5 / 5$ & Not very clear instructions. \\
\hline $\begin{array}{l}\text { Were you well prepared for the lesson, } \\
\text { did you have all the materials you } \\
\text { needed }\end{array}$ & $2 / 5$ & $\begin{array}{l}\text { Font on the PPT was very small, too much } \\
\text { content on the slides and did not prepare well } \\
\text { for the lesson. }\end{array}$ \\
\hline $\begin{array}{l}\text { Were the activities purposeful in } \\
\text { investigating the concept you want us } \\
\text { to learn (hands on part) }\end{array}$ & $1 / 5$ & $\begin{array}{l}\text { Activities were not very purposeful to help } \\
\text { students identify the parts as it is difficult for } \\
\text { them to identify parts without knowledge of } \\
\text { how they look or scientific explanation behind } \\
\text { why they look like that. I think planning an } \\
\text { intermediate activity like giving each table an } \\
\text { organelle to study and report to the class }\end{array}$ \\
\hline
\end{tabular}




\begin{tabular}{|c|c|c|}
\hline & & could have helped. \\
\hline $\begin{array}{l}\text { Were the discussions during and after } \\
\text { the activities purposeful in teaching us } \\
\text { about the concept }\end{array}$ & $2 / 5$ & $\begin{array}{l}\text { I think there needs to be more discussion. The } \\
\text { main activity was about the worksheet, and } \\
\text { there needs to be more discussion about that. } \\
\text { Encouraging students to discuss more helps } \\
\text { rather than just delivering lectures. } \\
\text { Asked students what they learnt from song } \\
\text { and to tell functions of parts in their own } \\
\text { words. Few replied as adults but not going to } \\
\text { work with kids, find ways to make students } \\
\text { talk more. }\end{array}$ \\
\hline $\begin{array}{l}\text { Did you have an interesting and } \\
\text { engaging assessment question that } \\
\text { pushed our thinking of the concept }\end{array}$ & $1 / 5$ & $\begin{array}{l}\text { No explicit assessment question. Lesson was } \\
\text { very vague did not push students thinking. }\end{array}$ \\
\hline $\begin{array}{l}\text { Did we learn the appropriate and } \\
\text { adequate scientific explanation from } \\
\text { this lesson }\end{array}$ & $0 / 5$ & $\begin{array}{l}\text { Firstly, parts of the cell and its functions are } \\
\text { not easy to teach in one class. It is not easy for } \\
\text { anybody to learn so much content in such a } \\
\text { little time. If someone already knows the } \\
\text { material, it's like a revision. However, if } \\
\text { someone is learning it, you need to have more } \\
\text { discussion and emphasis on the ideas to help } \\
\text { them learn about the lesson. }\end{array}$ \\
\hline $\begin{array}{l}\text { Did you have good eye contact, loud } \\
\text { enough voice and communicated } \\
\text { enthusiasm to the class? }\end{array}$ & $3 / 5$ & $\begin{array}{l}\text { Dull, could have raised your voices a bit } \\
\text { higher so that everyone in the room can hear } \\
\text { you. }\end{array}$ \\
\hline $\begin{array}{l}\text { Did you use different instructional } \\
\text { strategies and media sources? }\end{array}$ & $2 / 5$ & Yes, they did but not effectively. \\
\hline Timing: & $\begin{array}{l}25 \mathrm{minu} \\
\text { tes }\end{array}$ & \\
\hline TOTAL & $23 / 50$ & \\
\hline
\end{tabular}




\section{Appendix F}

Qualitative Description of Levels of Performance

\begin{tabular}{|l|l|l|}
\hline \multicolumn{1}{|c|}{$\begin{array}{c}\text { High } \\
\text { (40-50 points) }\end{array}$} & \multicolumn{1}{c|}{$\begin{array}{c}\text { Medium } \\
\text { (25-40 points) }\end{array}$} & $\begin{array}{c}\text { Low } \\
\text { (1-25 points) }\end{array}$ \\
\hline Excellent content knowledge. & $\begin{array}{l}\text { Good content knowledge but } \\
\text { having some incomplete } \\
\text { explanations. }\end{array}$ & Poor content knowledge. \\
\hline $\begin{array}{l}\text { Excellent understanding of 5E } \\
\text { inquiry model. }\end{array}$ & $\begin{array}{l}\text { Good understanding of 5E } \\
\text { inquiry model and mediocrely } \\
\text { motivated to implement inquiry } \\
\text { in their classrooms. }\end{array}$ & $\begin{array}{l}\text { Poor understanding of 5E } \\
\text { inquiry model and not } \\
\text { motivated to implement } \\
\text { inquiry in their classrooms. }\end{array}$ \\
\hline $\begin{array}{l}\text { Encouraging students highly to } \\
\text { think critically through } \\
\text { thought provoking questions. }\end{array}$ & $\begin{array}{l}\text { Some encouragement of critical } \\
\text { thinking by asking few thought } \\
\text { provoking questions. }\end{array}$ & $\begin{array}{l}\text { Fails to encourage students } \\
\text { to think critically. }\end{array}$ \\
\hline $\begin{array}{l}\text { Having all the 5E phases in } \\
\text { place. }\end{array}$ & $\begin{array}{l}\text { Having most but not all of 5E } \\
\text { phases in places. }\end{array}$ & $\begin{array}{l}\text { Skipping many phases of 5E } \\
\text { and fails in guiding } \\
\text { students through five } \\
\text { phases of inquiry. }\end{array}$ \\
\hline $\begin{array}{l}\text { Excellent classroom } \\
\text { management practices (This } \\
\text { criteria is only for peer teaching } \\
\text { sessions and not for lesson plans.) }\end{array}$ & $\begin{array}{l}\text { Good classroom management } \\
\text { practices (This criteria is only for } \\
\text { peer teaching sessions and not for } \\
\text { lesson plans) }\end{array}$ & $\begin{array}{l}\text { Poor classroom } \\
\text { management practices. (This } \\
\text { criteria is only for peer } \\
\text { teaching sessions and not for } \\
\text { lesson plans) }\end{array}$ \\
\hline
\end{tabular}


Appendix G

Data Analysis Table

\begin{tabular}{|c|c|c|}
\hline Data sources & Data Analytic Techniques & $\begin{array}{l}\text { Challenges (Themes) arising as a } \\
\text { result of the data analysis }\end{array}$ \\
\hline $\begin{array}{l}\text { Pre-Course Surveys, } \\
\text { Post-Course Surveys } \\
\text { and Interviews }\end{array}$ & $\begin{array}{l}\text { Data was coded axially and } \\
\text { constantly compared to extract the } \\
\text { challenges. I triangulated the data } \\
\text { sources to establish validity. }\end{array}$ & $\begin{array}{l}\text { - Lesson planning using } 5 \mathrm{E} \text { is } \\
\text { a time consuming process. }\end{array}$ \\
\hline $\begin{array}{l}\text { Post course surveys } \\
\text { and Interviews }\end{array}$ & $\begin{array}{l}\text { Data was coded axially and } \\
\text { constantly compared to extract the } \\
\text { challenges }\end{array}$ & $\begin{array}{l}\text { - Making lesson } \\
\text { understandable to every } \\
\text { student in the classroom is } \\
\text { challenging } \\
\text { - Transition between phases } \\
\text { of the } 5 \mathrm{E} \text { based lesson is } \\
\text { challenging }\end{array}$ \\
\hline $\begin{array}{l}\text { Field, Peer teaching } \\
\text { Lesson Plans and } \\
\text { Interviews }\end{array}$ & $\begin{array}{l}\text { Data was coded axially and } \\
\text { constantly compared to extract the } \\
\text { challenges. I triangulated the data } \\
\text { sources to establish validity. }\end{array}$ & $\begin{array}{l}\text { - Peer teaching is } \\
\text { challenging. }\end{array}$ \\
\hline $\begin{array}{l}\text { Peer Teaching } \\
\text { Lesson Plans, } \\
\text { Interviews and } \\
\text { Observational notes } \\
\text { from Peer Teaching } \\
\text { Sessions }\end{array}$ & $\begin{array}{l}\text { Data was axially coded. I compared } \\
\text { the challenges in the field and peer } \\
\text { teaching lesson plans to challenges } \\
\text { while implementing the lesson plan } \\
\text { during peer teaching using the } \\
\text { constant comparative method. Data } \\
\text { was triangulated for validity. }\end{array}$ & $\begin{array}{l}\text { Maintaining stringent time } \\
\text { slots for phases of the } 5 \mathrm{E} \text { is } \\
\text { challenging. }\end{array}$ \\
\hline $\begin{array}{l}\text { Field, Peer Teaching } \\
\text { lesson Plans and } \\
\text { Observational notes } \\
\text { collected from Peer } \\
\text { Teaching Sessions. }\end{array}$ & $\begin{array}{l}\text { Data was axially coded. I compared } \\
\text { the challenges in the field and peer } \\
\text { teaching lesson plans to challenges } \\
\text { while implementing the lesson plan } \\
\text { during peer teaching using the } \\
\text { constant comparative method. Data } \\
\text { was triangulated for validity. }\end{array}$ & $\begin{array}{l}\text { Writing and implementing } \\
\text { the explain phase of the 5E } \\
\text { is challenging. } \\
\text { Difficulty evaluating } \\
\text { students understanding. } \\
\text { - The elaborate phase of the } \\
\text { 5E is hard to think of. }\end{array}$ \\
\hline
\end{tabular}

